\title{
Uniting and Dividing Influences of Religion on Parent-Child Relationships in Highly Religious Families
}

\author{
Heather Howell Kelley \\ Brigham Young University - Provo \\ Loren D. Marks \\ Brigham Young University - Provo, loren_marks@byu.edu \\ David C. Dollahite \\ Brigham Young University, david_dollahite@byu.edu
}

Follow this and additional works at: https://scholarsarchive.byu.edu/facpub

Part of the Other Social and Behavioral Sciences Commons

\section{Original Publication Citation}

Kelley, H. H., Marks, L. D., \& Dollahite, D. C. (2020, May 14). Uniting and Dividing Influences of Religion on Parent-Child Relationships in Highly Religious Families. Psychology of Religion and Spirituality. Advance online publication.

\section{BYU ScholarsArchive Citation}

Kelley, Heather Howell; Marks, Loren D.; and Dollahite, David C., "Uniting and Dividing Influences of Religion on Parent-Child Relationships in Highly Religious Families" (2020). Faculty Publications. 4819. https://scholarsarchive.byu.edu/facpub/4819 accepted for inclusion in Faculty Publications by an authorized administrator of BYU ScholarsArchive. For more information, please contact ellen_amatangelo@byu.edu. 


\section{Psychology of Religion and Spirituality}

\section{Uniting and Dividing Influences of Religion on Parent- Child Relationships in Highly Religious Families}

Heather Howell Kelley, Loren D. Marks, and David C. Dollahite

Online First Publication, May 14, 2020. http://dx.doi.org/10.1037/rel0000321

\section{CITATION}

Kelley, H. H., Marks, L. D., \& Dollahite, D. C. (2020, May 14). Uniting and Dividing Influences of Religion on Parent-Child Relationships in Highly Religious Families. Psychology of Religion and Spirituality. Advance online publication. http://dx.doi.org/10.1037/rel0000321 


\title{
Uniting and Dividing Influences of Religion on Parent-Child Relationships in Highly Religious Families
}

\author{
Heather Howell Kelley, Loren D. Marks, and David C. Dollahite \\ Brigham Young University
}

\begin{abstract}
Religion can have both helpful and harmful influences on relationships. The purpose of this study is to better understand how religion can have both a unifying and a dividing influence on parent-child relationships. Through the use of interviews with 198 highly religious families ( $N=476$ individuals), we address some of the complexity inherent in religion and examine the influence of three dimensions of religious experience (religious practices, religious beliefs, and religious community). Findings are supported with primary qualitative data. For the highly religious parents and children in this study, 8 times as many unifying accounts of religion than dividing accounts were identified. However, a substantial number of dividing accounts were still found. Religion appeared to be particularly divisive when religious beliefs or practices conflicted with children's desire to fit in and spend time with their peer groups. Implications and suggestions for future research are offered.
\end{abstract}

Keywords: religion, parent-child relationships, qualitative, parenting, family

Religion and relationships are both complex, multifaceted constructs. Although much is still not understood at the nexus of religion and relationships, it is increasingly clear that religion can be both beneficial and detrimental to relationships (Dollahite, Marks, \& Dalton, 2018; Mahoney, 2005, 2010). Despite this, how religion can be both a help and a determinant to relationships has rarely been explored simultaneously (Marks \& Dollahite, 2017). Even though there has been an increase of more nuanced measures of religiosity as well as more qualitative research on religion and families in recent years, the majority of research on religion on family relationships is still based on only one or two measures of religiosity, such as self-reported church attendance or religious salience (Mahoney, 2010). Better methodologies are needed to better understand the how and why of religion's influence on children and families (King \& Boyatzis, 2015). Specifically, more research is needed that (1) looks at the influences of multiple dimensions of religion on relationships, (2) is truly family research in terms of including the perspectives of multiple family members (Handel, 1996), and (3) that intentionally seeks to better understand both the beneficial and detrimental influences of religion on families.

In the current study, we attempt to integrate all three of these aspects through using a large qualitative sample that includes parents and children interviewed together and by examining both unifying and dividing influences of religious beliefs, practices, and communities on parent-child relationships in highly religious,

(D) Heather Howell Kelley, Loren D. Marks, and David C. Dollahite, School of Family Life, Brigham Young University.

Correspondence concerning this article should be addressed to Heather Howell Kelley, School of Family Life, Brigham Young University, 2092a Joseph F. Smith Building, Provo, UT 84604. E-mail: hhowell3@byu.edu shared-faith families. This study is the second part in a two-part project. The first part focused on the uniting and dividng influences of religion in shared-faith marriages (Kelley, Marks, \& Dollahite, 2020). The relevant findings of this preceding study will be explored in conjunction with the findings of this study in the Discussion section.

\section{Theoretical Foundations}

A recent article by Dollahite et al. (2018) presented a conceptual model of a system of dualities to explain why religion can be both helpful and harmful in families. One of the eight proposed dualities is that "religion in families may be relationally divisive and unifying" (Dollahite et al., 2018, p. 219). In response to their invitation to further examine and research these dualities, this article explores this dividing and uniting duality in depth among parentchild relationships. Dollahite et al. defined relational unity as "harmony with family members and others resulting from religious belief, practice, identity, and traditions" and relational division as "disharmony with family members and others resulting from religious belief, identity, obligations, and choices" (p. 30). Based on these definitions and on the literature, unifying influences are operationalized in this study as any positive processes and outcomes, such as more positive interactions between parents and children or reduced parenting stress (Henderson, Uecker, \& Stroope, 2016; Wilcox, 2004) that strengthen relationships and bring parents and children closer together. The literature surrounding the disharmony that religion creates in families generally focuses on struggles (Exline, Pargament, Grubbs, \& Yali, 2014; Exline \& Rose, 2005) and conflict (Stokes \& Regnerus, 2009). In analyzing the divisive influence of religion, these constructs and other subtler influences are explored.

Previous work presents three dimensions of religion that represent distinct dimensions of religiosity: beliefs, practice, and community (Marks, 2005). Religious practices include actions such as 
church attendance, prayer, and acts of abstinence (e.g., fasting, abstaining from sex before marriage, etc.). Beliefs include the meanings, perspectives, identities, and internal ideals that stem from religion, whereas community refers to the support, involvement, obligations, and relationships that are grounded within a religious group. Religious communities provide valuable social support and form some of the most important relationships outside the family (Krause, 2008) and might also have important impacts on familial relationships (Kelley et al., 2020). Each of these three dimensions of religion (beliefs, practices, and community) are examined in our effort to address some of the complexity inherent in religion.

\section{Religious Beliefs, Practices, and Community and Parent-Child Relationships}

Although beliefs, practices, and community are useful constructs in painting a more complete picture of the role religion plays in uniting and dividing parent-child relationships, they are not perfectly distinct and separate constructs. There is some overlap and gray area between these constructs. One example of this is attending worship services, which is both a religious practice and being part of the religious community. For the purposes of this study, attending a regular worship service was considered a religious practice, whereas anything beyond attendance (e.g., interactions with community members or being involved in multiple meetings and groups within the religious community) was considered being part of religious community. Despite the limitation of some conceptual overlap among these constructs, they remain valuable tools in directing and organizing the extant and current research on religion.

\section{Religious Beliefs}

Beliefs regarding the sanctity and importance of parenting have been associated with benefits such as increased parenting satisfaction (Henderson et al., 2016; Nelson \& Uecker, 2018), more positive mother-child interactions among biblically conservative mothers (Murray-Swank, Mahoney, \& Pargament, 2006), and parents' use of positive socialization and children's conscience development (Volling, Mahoney, \& Rauer, 2009). The sanctification of parenting and other religious beliefs can also help families cope with, reduce, or overcome divisive challenges such as behavior problems and parenting related stress (Weyand, O'Laughlin, \& Bennett, 2013).

Despite the many benefits religious beliefs can bring to parentchild relationships, they can also have detrimental effects on the same relationships. For example, biblical conservatism along with the sanctification of parenting has been linked with higher use and acceptance of corporal punishment (Murray-Swank et al., 2006). The outcomes of corporal punishment for children appear to vary depending on the family's beliefs and whether there is a shared acceptance of and adherence to their religion's rules regarding corporal punishment (Petts \& Kysar-Moon, 2012). Whereas specific religious beliefs can create some problems for parents and children, having different beliefs in general or differing worldviews can also be divisive. For many, adolescence can be a time of religious change, including both increases and decreases in religiosity, though declines in religiosity are more common (Regnerus
\& Uecker, 2006; Uecker, Regnerus, \& Vaaler, 2007). Such changes in adolescent beliefs and the resulting differences and conflicts about religious beliefs between parents and children can be detrimental to child well-being (Bartkowski, Xu, \& Levin, 2008) and can also decrease parent-child relationship quality (Petts \& Knoester, 2007; Stokes \& Regnerus, 2009). The outcomes of these differing beliefs vary greatly. Although some differences in beliefs are harmless or at least manageable, others can be detrimental to the relationship, often depending on the salience of the belief (Mahoney, 2005; Stokes \& Regnerus, 2009).

\section{Religious Practices}

Religious practices such as prayer, scripture study, and attending worship services can have important influences on parentchild relationships. A study measuring the associations between religious beliefs and practices and parents spending meaningful time with children outside of religious obligations suggested that religious practices actually mediated the association between religious beliefs and increased quality time spent with children (Jorgensen, Mancini, Yorgason, \& Day, 2016). Religious practices appear to influence parent-child relationships across religious denominations. A recent special issue exploring strengths of eight different religious-ethnic groups described important benefits of religious practices across these groups. For example, Jewish families observing Shabbat provided important time for children and parents to bond (Kelley et al., 2018), whereas communion and prayer reportedly helped parents navigate conflict with increased patience among Catholic and Orthodox Christian families (White et al., 2018). Indeed, various benefits of prayer have been described across multiple studies. Using nationally representative data, Bartkowski and colleagues (2008) found that family prayer was tied to better child adjustment, whereas another recent study found that family prayer helped facilitate forgiveness and greater family unity, among other benefits (Chelladurai, Dollahite, \& Marks, 2018).

The ways religious practices are expressed within families can also create challenges and might lead to division among family members (Burr, Marks, \& Day, 2012). For example, despite the benefits of prayer indicated earlier, researchers have suggested that joint prayer might be used to criticize or manipulate others participating in the prayer (Lambert, Fincham, LaVallee, \& Brantley, 2012), though no research to our knowledge has specifically identified prayer as a tool for criticism or manipulation among parents and children. Other instances of dividing practices might also include disagreements over participating in certain religious practices. For example, Stokes and Regnerus (2009) found that children attending church to a lesser extent than their parents was associated with lower quality parent-child relationships. However, they noted this association was likely attributable to differing levels of religious salience (beliefs) between the parents and children than to the practice itself. Overall, there appears to be little research that describes specific religious practices that are harmful for parent-child relationships.

\section{Religious Community}

The dimension of religious community can also have a major influence on family relationships. On the unifying side, religious 
communities provide important support for parents and for parentchild relationships (Mahoney, 2010). However, certain types of religious demands can be harmful and divisive for families (Burr et al., 2012). For example, Nelson and Uecker (2018) noted that the benefits of beliefs regarding the sanctity of parenting might be undermined by pressures to excel in parenting from certain religious communities that place a strong emphasis on family life. Additionally, when family stressors occur that are not in line with the expectations of the religious community, such as divorce or childbearing outside of marriage, the religious community might exacerbate these challenges (Dollahite, Marks, \& Goodman, 2004). Relatedly, nontraditional families might face more challenges within a religious community and might receive fewer benefits than traditional families do (Marks \& Dollahite, 2017).

\section{Current Study}

The purpose of this study is to explore ways religion influences parent-child relationships among highly religious families. The associations between religion and relationships appear to be complex and mixed. For example, Bornstein et al.'s (2017) landmark study of 1198 families measuring the associations between religion, parenting, and child adjustment found that greater parental religiousness was associated with both positive and negative outcomes for parenting and child adjustment. Interestingly, whereas the parents in the study associated religiousness with increased parental efficacy and warmth, some of their children associated religiousness with parental rejection (Bornstein et al., 2017). For this reason, in addition to looking at beliefs, practices, and community, both parent and children responses are analyzed in this study.

\section{Method}

\section{Sample}

This study used data from the American Families of Faith project (Marks \& Dollahite, 2017). The sample consists of 198 married, heterosexual couples who were raising or had raised at least one child together. In $55(27 \%)$ of the interviews, adolescent or young adult children joined their parents for the interview $(N=$ 476 individuals; 396 parents and 80 children aged 10 to 25 years). Parents had been married an average of 20 years and were on average in their mid- to late $40 \mathrm{~s}$ (mothers $=45$ years, fathers $=$ 47 years). Most of the children, $56 \%$, were high school aged (14 to 17 years), $23 \%$ were 10 to 13 years, and the remaining $25 \%$ were between 18 and 25 years. We note that individuals who are 18 years or older are technically not children per a legal or American Psychological Association format perspective, we did not analyze responses for age differences. Thus, for linguistic simplicity we refer to all offspring participants as children.

Families were from the three major Abrahamic faiths (Judaism, Christianity, Islam). Participants were selected from all eight religiously diverse regions of the United States (Silk \& Walsh, 2011). After obtaining institutional review board approval from the researchers' university, diverse clergy were contacted and asked to identify strong, marriage-based families (with at least one child) who were committed to and involved in their faith. The recommended families were then contacted to determine willingness to participate. Families were purposively sampled (Denzin \& Lincoln, 1994) with an intentional oversampling (50.5\%) of racial and ethnic minorities (16\% African American, 12\% Asian American, 8.5\% Middle Eastern, 5.5\% Latino, 5\% Native American, 3\% East Asian, and $0.5 \%$ Pacific Islander families). Among more difficultto-access faiths (e.g., Islam, Orthodox Judaism), participant referral sampling was also used. The final sample included 22 denominations of Abrahamic religions. Thus, the sample is characterized by (1) a high level of religious commitment, (2) religious diversity, (3) a wide range of socioeconomic and educational levels, (4) racial/ethnic diversity, and (5) geographic diversity.

\section{Interview Procedure}

Questions were pretested to identify potential problems. Husbands and wives were interviewed together in their home, and in the 55 interviews that included children, the parents and children were interviewed together to allow them to interact and build from or revise each other's responses (Lofland \& Lofland, 1995) in a reciprocal and bidirectional manner that allowed the children to have agency so as to direct conversations, express their ideas, and terminate the conversation (Boyatzis, 2011; King \& Boyatzis, 2015). Although interviewing children and parents together might result in more socially desirable responses, research has shown that, on average, adolescents from highly religious families reported being able to talk about religion open and honestly with their parents (Smith \& Denton, 2009). Additionally, as one quarter of the "children" were over 18 years of age, this might have reduced the influence of social desirability to some degree. Previous research from this dataset analyzing how parents and children talk about religion found that most often, parents and children were able to openly discuss differences and disagreements in a way that allowed all of their voices to be heard (Dollahite \& Thatcher, 2008). Thus, whereas interviewing family members together might increase social desirability bias in some situations, it might also lead family members to be honest and prevent them from misrepresenting their family life in other situations.

Questions were open-ended with follow-up questions to clarify and add depth to the initial responses. Interviews typically consisted of 26 questions and lasted about $2 \mathrm{hr}$. Questions focused on connections between religion, marriage, parenting, and family life. The interviews were transcribed verbatim and coded, as described in the following section. No questions asked specifically about the unifying nor the dividing influences of religion. However, questions were asked regarding how religion strengthened the participant's families, what role religion played in their relationships, and which religious teachings or practices were most meaningful to them. These questions elicited many of the unifying accounts. These questions also revealed some dividing accounts, often through the conversation they started between the participants. Dividing accounts also came from questions regarding challenges the family was facing and whether there were any religious beliefs or practices that were harmful, including when the belief or practice was misunderstood or misapplied.

\section{Measures and Coding Process}

A team-based approach to systematically analyzing qualitative data was used (Levitt et al., 2018; Marks, 2015). Data went 
through several phases of analysis. The first phase was done by one group of coders and secondary analyses were performed by a different group of coders. Coders consisted primarily of students enrolled in a semester-long research course. In this course, coders were taught the coding process, including how to use NVivo 10 and NVivo 11 (NVivo 10, 2014; NVivo 11, 2015) and the overarching ideas they would be coding. Meetings were held at least twice a month to ascertain progress and to ensure interrater reliability.

Initial analyses. Coders involved in the primary analyses read through the transcriptions of interviews in NVivo 10 and NVivo 11 (NVivo 10, 2014; NVivo 11, 2015) and categorized what participants said into unifying and dividing codes. Students were given a codebook to help them determine when they could categorize what a participant said as an example of the dividing or unifying nature of religion. The codebook was created following procedures described by MacQueen, McLellan, Kay, and Milstein (1998) and Bernard, Wutich, and Ryan (2016). The themes of religion unifying and dividing were included within a larger coding project and these initial analyses required several semesters. ${ }^{1}$ Coders were first assigned transcripts to read through and identify possible examples of religion uniting and dividing, based on the codebook. Reports and feedback about progress were exchanged through in-person meetings and e-mail correspondence. Coders were then given copies of another coder's work to read through and make notes of any disagreements about unites and divides codes (for check and balance purposes and to ensure interrater reliability). The original coder then met with the reviewer and they discussed whether they agreed with the reviewer's assessment and made a final decision on the code. A graduate student went through these decisions and made appropriate changes in the coding files so that secondary analyses could be conducted.

Secondary analyses. Secondary analyses were completed in a two-step process. The first step utilized open coding to create a codebook, which was completed by the first author and one undergraduate student. The second step utilized a conceptual codebook to code interviews according to the themes identified through a brief review of the literature. Both steps used coders enrolled in a semester-long research course. Two part-time paid research assistants also assisted in the open coding.

Open coding. The first author and one paid undergraduate research assistant open coded the already selected accounts of unites and divides. Each were given a select number of interviews to read and identify subthemes within the accounts previously identified as unites or divides that seemed to be found across multiple interviews. Biweekly meetings were held to discuss these ideas and come to an agreement on a codebook. Four additional coders then used this codebook to code the remaining interviews. This level of coding primarily identified which relationships were being divided (e.g., familial, congregational) as well as some of the causes of the unity or division (e.g., misunderstandings, stress created by religion). Not all the themes identified at this stage appear in the article; some might be explored in future articles.

Conceptual coding. After open coding was completed, an additional round of coding was done. Based on themes present in open coding and on previous research, the author identified religious beliefs, practices, and community as useful constructs to explore various dimensions religion and subsequently created a codebook. Four groups of two students $(N=8)$ utilized this codebook to code all identified unifying and dividing accounts from the 198 interviews. Interviews were divided between the four groups of students, so that each group was responsible for analyzing a quarter of the data. Within each pair of students, each student individually coded their allotted data. Then, each partner reviewed their partner's coding and recorded any disagreements and vice versa. Coders then met together to discuss these disagreements and decided which secondary analysis decisions should be kept or deleted (Levitt et al., 2018). The individual files were then merged, and Cohen's kappa was calculated in NVivo 11 (NVivo 11, 2015) to measure interrater reliability. The four groups of coders ranged from .65 to .75 , with an average of .69, suggesting substantial interrater agreement (Landis \& Koch, 1977).

\section{Reflexivity}

Reflexivity refers to researchers exploring and openly reporting their own assumptions, personal experiences, and other biases that might influence their research and trying to minimize those biases (Daly, 2008). All three authors are married parents and are active members of faith communities, placing us in an emic or insider position in terms of religious involvement. Based on personal beliefs and experiences, we are predisposed to focus on the positive influence of religion. To reduce biases stemming from our personal views, we selected a diverse (e.g., race, gender, age, religious backgrounds) group of students to aid in completing the secondary coding analyses. Further, we systematically searched for challenging and/or divisive influences of religion.

\section{Findings}

Findings regarding the unifying and dividing influence of religion on parent-child relationships are presented in the following text. Table 1 presents a summary of these findings, and Table 2 presents a numeric content analysis of the reported themes (Levitt et al., 2018).

\section{Theme 1: Religious Beliefs}

Theme 1, Concept A: Unifying beliefs in parent-child relationships. There were 232 accounts regarding unifying beliefs in parent-child relationships, many of which were focused on the responsibilities of parents toward their children. These responsibilities included being a good example for them, loving them, caring for them, and teaching them good principles. Jala described her key responsibilities as a Muslim mother:

I think it's real important to understand that there's no compulsion in Islam, and with that, as a mother in Islam, teaching your children, educating them, is the key for a mother in Islam. I . . . can only [teach]

\footnotetext{
${ }^{1}$ As previously noted, the operational definition of unites focuses on connections, bonds, and relationships among individuals and others, including God, family members, members of their congregations, and those outside their religious community. The operational definition of divides includes any exclusion, separation, criticism of others, as well as and conflict with others.
} 
Table 1

Summary of Findings

1a. Unifying beliefs in parent-child relationships

Theme 1. Religious beliefs

i. Specific beliefs regarding the importance of parent-child relationships and beliefs regarding child-rearing responsibilities

ii. Shared beliefs create a common ground between parents and children

iii. Children become parents' primary focus

1b. Dividing beliefs in parent-child relationships

i. Dissonance between religious beliefs and popular culture

ii. Differences between couples and their families of origin who belong to a different religion or have different beliefs

2a. Unifying practices in parent-child relationships

Theme 2. Religious practices

i. Religious practices often result in quality time spent as a family

ii. Certain practices, particularly prayer, provided parenting guidance

iii. Gender-based practices resulted in one-on-one time between children and their parent of the same sex

2b. Dividing practices in parent-child relationships

i. Children want to participate in activities that conflict with religious practices

ii. Children's desire to fit in with their peers conflicts with the religious practices in which parents desire their children to participate

3a. Unifying influence of community on parent-child relationships

Theme 3. Religious community

i. Support in raising child

ii. Provides parents and children a shared community to interact with each other in

3b. Dividing influence of community on parent-child relationship

i. Spending time serving members of the religious community takes away from time with children and may increase parenting stress

them, you know, [to enjoy] what is good, forbid what is wrong, and hope and pray that they could go on the right path because we [are] taught that in Islam that there is [to be] no compulsion.

Jala's beliefs reportedly led her to not only strive to teach her children to the best of her knowledge and ability, but to also respect them and their autonomy.

Respect between parents and children was also important to many families, as is illustrated in the following examples. Dewei, an Asian Christian father said, "In our family, I am the father of my son, but we are also brothers. This is very important, and we are equal. I regard him as a little brother, and we grow up together in Christ." The final phrase of this account, growing "together in Christ," hints at another identified concept, namely that "shared faith brings family together." Devon, a Baptist son, similarly referred to his family's faith as providing a "common ground between us." For Micah, a 15-year-old Jewish son, this common ground religion provided helped reduce conflict with his parents. Micah said, "I think if I wasn't Jewish, then I would argue with my parents more than I do now."

In addition to providing common ground for parents and children, religious beliefs also helped children and parents to recognize the importance of their relationship with each other. Krystal, a 12-year-old Latter-day Saint daughter expressed how her belief in an afterlife, where she would be with her parents helped her to "create a bond" with her parents. Although Krystal cited a specific belief that helped her bond with her parents, for one Christian family, it was their religious journey that they reported united their family. This family identifies as "Sabbath keeping Christians" and have attended various churches. They report often discussing their religious beliefs as a family, including having some disagreements with what they are taught in church, as is shown in the following conversation

Table 2

Numerical Content Analysis of Qualitative Coding

\begin{tabular}{|c|c|c|c|c|}
\hline Theme & No. of references & No. of sources & Interviews & $\begin{array}{l}\text { Average no. of } \\
\text { references per source }\end{array}$ \\
\hline \multicolumn{5}{|l|}{ Theme1: Religious beliefs } \\
\hline 1a. Unifying beliefs: parent-child & 232 & 96 & $48.5 \%$ & 2.4 \\
\hline 1b. Dividing beliefs: parent-child & 41 & 32 & $16.2 \%$ & 1.3 \\
\hline \multicolumn{5}{|l|}{ Theme 2: Religious practices } \\
\hline 2a. Unifying practices: parent-child & 496 & 135 & $68.2 \%$ & 3.7 \\
\hline 2b. Dividing practices: parent-child & 53 & 39 & $19.7 \%$ & 1.4 \\
\hline \multicolumn{5}{|l|}{ Theme 3: Religious community } \\
\hline 3a. Unifying community: parent-child & 86 & 59 & $29.8 \%$ & 1.5 \\
\hline 3b. Dividing community: parent-child & 7 & 7 & $3.5 \%$ & 1 \\
\hline Total & 915 & 184 & $93 \%$ & 5 \\
\hline
\end{tabular}

Note. The percentage of interviews is calculated as the number of sources divided by the total number of interviews $(n=198)$. The average references per source is calculated as the number of references divided by the number of sources in which the theme was identified. 
between Wes, an 18-year-old son, and his older sister, Aubrey, a 20-year-old daughter.

\begin{abstract}
We have the same church or religious background. Now we're going to the Seventh-day Adventist church, we hear things said, we hear things, [and] we make a note in our mind-I do not know if I agree with that. Come home... [and] it's like a discussion between your family. "Cause basically we think the same thing most of the time. (Wes)
\end{abstract}

Basically the only people we can discuss this with is our family, because no one else has been on the religious roller coaster ride that we have. (Aubrey)

Religious beliefs also appear to motivate parents to make their children their primary focus and to thus spend more time with their children than they did in other pursuits, including careers. A Christian mother named Charlene invested heavily in her children, particularly when they were young, and she explained as follows:

[M]y religion helps answer some questions for me that the world might answer in different ways. So instead of having to struggle ... when my kids are teenagers, wish[ing] that I had been there with them, I already knew what was the right thing to do, so I did it. Even though there were some struggles with it ... I [now] see the fruits of my labors and I'm so grateful that I had that guidance.

Although Charlene ultimately expressed her gratitude for the guidance she gained in parenting from her religious beliefs, she noted that these decisions were not without struggle for her. Although religious beliefs appeared to have a unifying influence in many situations, they also appeared to create struggles and have a dividing influence on parent-child relationships, as is discussed next.

Theme 1, Concept B: Dividing beliefs in parent-child relationships. Although there were fewer accounts identified regarding the dividing influence of beliefs than the unifying influence of beliefs, there was a still a substantial number of such accounts $(n=41)$. Anthony, a 17-year-old son, expressed that differing beliefs were a regular occurrence for him and his parents. When asked how conversations on religion with his parents typically go, he responded, "Usually we express different viewpoints." Despite these differences, Anthony followed up this statement by saying that these conversations were typically a learning experience for him and were often "all cool." This account suggests that differing might not always be necessarily divisive for parents and children. The divisive potential of a belief might depend on what the belief is and how it is addressed.

The beliefs that most often appeared to have a divisive influence on parent-child relationships resulted from dissonance between religious beliefs and popular culture. Many of these accounts described how parents' efforts to encourage children to live according to various religious beliefs introduced tension and frustration to the relationship. For example, while discussing what they allowed and did not allow into their home, one Asian Christian father, Jianguo, recounted, "We didn't encourage them to read Harry Potter, but Jeffery wanted to read it and he began to feel frustrated [with us]." Although the magic and witchcraft elements in the Harry Potter series were well accepted in society, they conflicted with some of the teachings and beliefs Jianguo desired to pass onto his children. The kind of culture versus religion frustration that Jianguo mentioned was reported by both children and parents. Candace, an Episcopalian mother, recounted the following:

[Our daughter] is constantly wanting stuff, constantly wanting to buy stuff and acquire stuff. It is always things ... mostly materialistic, and it's very frustrating to us. It is a real concern and seems like a real distraction, but it's not easy to parent [it] out of her. It's in her and reflected in the culture.

These preceding accounts presented some of the struggles that took place between parents and children within the home and were related to how beliefs were expressed in terms of rules and restrictions. The dividing accounts that generally took place outside of the home dealt with the parents in this sample differing in beliefs and even belief-systems from their family of origin. There was a great deal of variance in the resulting apparent influence of these differing beliefs on the parent-child relationship. Ziva, a nolonger-practicing Catholic who was raising her children Jewish, explained the concern her "very, very" Catholic father felt for her:

[My father] thinks that I've given up something very big . . . My father doesn't ever say anything about it, so it's not like it's an argument between us, but I know that he is concerned, because he is a very, very, deeply religious person.

For this father and daughter, religion appeared to be a source of division which they coped with by avoiding the subject. Moriah, a Jewish mother, similarly explained how her husband's nonreligious parents struggled to understand their religiosity. Moriah stated, "I think [my husband's] parents, being non-religious, think [he has] given up a lot, because they don't understand what [he gets] out of . . . all the traditional things that we do. They don't see how it could possibly enrich [our lives]." Although these previous accounts demonstrate how differing beliefs can make it harder to connect, for others, such as Gary, a Black Methodist, this inability to understand others' beliefs was much more divisive. He said, "For the most part, 99\% of the time, I can't talk to my mom, or [my siblings]. Because their walks are different than mine. I mean everyone's walk is different, but their relationship with God [is very different]."

For some, religious beliefs are a fundamental part of their identity and helped create a shared identity. However, religious beliefs can also be divisive when such beliefs are not shared or are (in some cases) quite different. The next section explores how religious practices might similarly have both a unifying and dividing influence on parent-child relationships.

\section{Theme 2: Religious Practices}

Theme 2, Concept A: Unifying practices in parent-child relationships. There were 496 accounts that were identified by our coding team as unifying practices in parent-child relationships. Time was identified as a prominent theme throughout this section. Whether it was reading scriptures together, praying, attending worship services, or family night, religious practices provided meaningful time for parents and children to spend together. Nadira, a Muslim daughter, described how various Islamic practices united her family:

[We say] prayers together as an entire family, most evenings ... we read from the religious books and talk about Islam and the values, which in your daily life, you can sometimes forget [and the] reminder 
to everyone again is done as a family. So many of those things, [it] is not ... one act. The religious holidays ... fasting together [and] breaking the fast together. Going on the pilgrimage together.

As illustrated by this preceding account, various religious practices created many opportunities for Nadira and her siblings to spend time with their parents. For many participants, such time spent together participating in religious practices was highly meaningful, and mutually beneficial and strengthening. This is also reflected in the following account from a Christian son who described how his religious home and rituals strengthened and unified his family:

There's an equal goal. Everybody serves God. And as a family, [this] serves as a function to help each other. So, we all kind of help each other develop. You know, parents help us, we help the parents ... The parents do a lot of teaching and raising of us, me and [my brother]. We in return ... serve God through serving them.

Whereas the preceding account did not elaborate on the specific practices that unify the family, it is evident that the common goal of serving God guided many of the family's interactions and practices, whether these practices were done together or individually. Many participants reported that practices that were done individually, particularly prayer, also had a positive, unifying influence on their parent-child relationships. Melinda, a Pentecostal mother, described how prayer guided her and her husband's parenting and strengthened their relationships with their children, saying, "We pray for our children, individually ... We ask God for guidance. . . [to] teach us how to deal with kids and the problems, and all that stuff. That creates a stronger bond ... and it helps me with the parenting." Praying for their children and asking God for help and guidance in parenting was a frequent occurrence among our sample. A Christian mother named Tara called it "a constant conversation with God."

It is also important to note here that a previous article regarding the uniting and dividing influences of religion on marital relationships (Kelley et al., 2020) found that some gender-based practices appeared to have a dividing influence in marital relationships, such as men leaving their wives to go pray at a religious service. However, the present analysis identified gender-based practices as often having a unifying influence on parent-child relationships, as they appeared to provide important bonding between fathers and sons, or mothers and daughters. A Jewish mother said the following:

When our kids were younger we did Shabbat dinners every Friday night and it was really fun for all of us I think. My daughter would run upstairs and put on her special Shabbat clothes and she and I would make challah together.

Whether if it was a mother and daughter making challah (braided bread) together or sons accompanying their fathers to pray, these gender-based religious practices often provided one-on-one time between fathers and sons and mothers and daughters.

Theme 2, Concept B: Dividing practices in parent-child relationships. There were 53 accounts coded as dividing practices in parent-child relationships. The most common accounts identified in this section appeared when religious practices conflicted with what the children wanted to do with their friends, or how they wanted to be perceived by their peers. For example, a common conflict our sample dealt with were sports or other events that took place during their worship services or other family practices. Dmisha, a Jewish mother, described how the activities her oldest daughter wanted to do with friends on Shabbat created conflict:

We had a rule for the girls. The oldest one was old enough to date and go out, and she wanted to go out on Fridays. I mean, she basically didn't want to come home on Friday. She wanted to go to the football games and date and do things and I said, "No. It's Shabbat. You come home. You have friends you want to be with? Invite them. We'll feed them too! And you will be with the family until 8 or 8:30 at night and then after that you can go out." And that was just looked upon as terribly restrictive.

Beyond feeling restricted by religious practices, children also expressed feelings of embarrassment and isolation from their peers, and these feelings often led to conflict with their parents. Jennifer, a Jehovah's Witness, expressed how their children struggled with the missionary work they did, saying, "The door-to-door in the ministry. When the kids get to a certain age, that can be embarrassing [to them]." Sara, a Jewish daughter, recalled why religious practices led her to struggle with her parents:

\begin{abstract}
It was a struggle, like I do not want to go to services, like none of my friends have to go to services on Saturdays, or . . . to . . . a boring Bar Mitzvah, I do not want to go. Nobody else I know has to go ... I think, like the strongest sort of challenges ... come from when you feel like being Jewish like isolates you from your friends, or isolates you from the surrounding area, or that having any sort of strong faith isolates you.
\end{abstract}

During adolescence, the children of these highly religious parents in our sample seemed to struggle finding balance between the demands of their religion and religious practices and the demands and desires of their social life. For some, this did create conflict in the parent-child relationship, whereas others were able work with their parents to figure out a balance that worked for both of them. Kira, a Lutheran mother, described how her experience raising her children in a religious household varied greatly between the children:

Every child and parent have a different relationship, and each kid reacts to different things. Some you might be able to just throw the Bible at them and say, "Read this and get back to me" and they can learn it. Others. . . [might need to be] exposed to sermon and. . . [I] throw a question, a very nonthreatening question, to them about the sermon and see if they bite and start ... talking about it.

In this account, Kira expressed how each child learned and responded differently to religious practices and religious socialization efforts. Even within the same family, what might have been unifying for one parent-child relationship could be divisive for another. It seems that how the practice was enacted and perceived in the family was a better determiner of the unifying or dividing relational influence it might have rather than what the practice was.

\section{Theme 3: Religious Community}

Overall, there were far fewer accounts identified regarding the unifying or dividing influence of religious communities on family relationships. Despite that these accounts were less prevalent than the accounts identified as unifying and dividing beliefs and prac- 
tices, community still played a salient role in parent-child relationships for many of our participants.

According to our analyses, community had a primarily unifying influence on these relationships, and rarely a divisive influence. This is in part due to the coding criteria that were used. As there can be conceptual overlap between some religious practices and community, these two constructs were distinguished in the following way. The act of attending a worship service was coded under religious practices and not community. Any time spent beyond regular practices, including interactions with community members, or any service given to or received from the members of the religious community was coded under community.

Theme 3, Concept A: Unifying influences of community in parent-child relationships. There were 86 accounts coded as unifying influences of community in parent-child relationships. These accounts mainly dealt with the support parents gained from their community, the examples of other parents in their community, and the common ground religious communities provided for parents and children. One Christian couple recalled the physical support they received as they faced challenges surrounding the birth of their first son:

Our first son was born 2 months premature and was in the hospital for 3 weeks. We didn't have a car and it was halfway across town to the hospital, [but] people gave us rides. (Michael)

\begin{abstract}
Almost every day for 3 weeks, someone would come pick me up at our house at 8:00 [in the morning] and take me to the hospital so I could spend the day there nursing and caring for our baby, and then at 8:00 at night somebody would come and pick us up and give us [a] ride home, which was huge ... It was a bonding experience. We could never leave [our city] because we owe the [congregation] too much. (Linda)
\end{abstract}

The support of the congregation allowed this family to bond with their newborn son.

Arella, a Jewish mother, described how her religious community provided bonding time with her children by creating a shared social group:

[Judaism] defines our social circle ... the majority of our friends are Jewish because we go there for Friday night dinners or they come here. We share holidays together, and so it defines again who we are, who our friends are, who our kids' friends are.

Efrem, a Jewish father, similarly described how his religious community helped him be more connected with his children and be more aware of their social life. In response to a question regarding how his involvement in religion had influenced his parenting, he said, "Being . . . an active part of a larger community just helps me see the connection between our kids and our family and the community and then thereby, our kids in the community." A Muslim daughter similarly described the importance of her religious community by referring to it and her Mosque as a "second home" for her and her parents.

Theme 3, Concept B: Dividing influences of community in parent-child relationships. The divisive influence of community on parent-child relationships was nearly nonexistent, with only seven accounts coded as such. Most of these dealt with the time commitment some religious communities demand of parents. As mentioned previously, attending worship services was coded under religious practices, not religious community. Thus, the accounts in this section went beyond the regular religious practices and attendance, to the demands of interacting with and serving the members of the religious community. One Christian father expressed how his involvement in their religious community seemed to prevent him from being able to see his young children some days and increased parenting-related stress for his wife, saying the following:

I began to serve in church as a deacon. My two children were still young then and I was busy with my work. We had Sunday school and worship at morning, Chinese school at afternoon, and prayer meeting at night (for missionaries). Sometimes I was not at home the whole day and she complained.

A Latter-day Saint couple similarly described how overinvolvement in and expectations from their religious community could put strain on their parenting responsibilities and family relationships:

We are so committed [to] serve in this church. You know, we dedicate our lives and a lot of time and effort into programs in the church, helping the youth with camp, helping [children in] Primary ... and I think that can be taken to an extreme to where you can neglect your family, "cause you are to serve the Lord with all your heart, might, mind and strength, but part of that is taking care of your family first. . . . (Heidi)

There's a perception in our church that you have you to be perfect. That you have to do everything just right and the supermom or the superdad does the priesthood thing, does the family home evening thing, does the scripture study, does the date night ... Sometimes $\therefore$ can be so much pressure to do that, [so] if you fall short or . . . just do not have the time to be the camp director and the seminary teacher ... sometimes that brings some guilt into the life and sometimes [family] relationship $[\mathrm{s}]$ can be ... challenged by that. (Mason)

The preceding account again demonstrates that it was generally not the religion that was inherently divisive, but rather how the family applied principles of the religion. Although this family's faith emphasized the importance of serving their community, their faith also taught that family should come first. However, this family struggled at times to balance these teachings, and it was when they were out of balance that the religion reportedly had a divisive influence.

\section{Discussion}

Through qualitative analyses of interviews with 198 highly religious families $(N=476)$, this study identified ways religion can have both a unifying and dividing influence on parent-child relationships. Among this sample of highly religious families, across beliefs, practices, and community, far more unifying accounts (approximately five to 12 times as many accounts across the three themes) were identified than dividing accounts. This is likely due in part to the strengths-based, shared-faith, highly religious and nongeneralizable nature of the sample, but it is also likely due, in part, to the central importance of family in the Abrahamic faiths. Christianity, Judaism, and Islam all include the importance of marriage and parenting among their fundamental doctrines (Agius \& Chircop, 1998). As illustrated by the high number of unifying accounts, it appears that these teachings and doctrines might have a tangible influence on parent-child rela- 
tionships in highly religious families. However, even among highly religious, shared-faith families, results suggested that religion can still have a dividing influence. This was most often seen when the religious values and what the parents' wanted their children to do conflicted with more worldly or secular values and what the children wanted to do or how they wanted to be perceived by peers outside of their religious community. Although the parents focused on and tried to facilitate greater familial unity, it appears that, at times, this created conflict when children placed greater value on unity with their peer group. In his volume on religious violence, Rabbi Jonathan Sacks (2015) stated the following:

Groups unite and divide. They divide as they unite. Every group involves the coming together of multiple individuals to form a collective Us. But every Us is defined against a Them, the ones not like us ... Inclusion and exclusion go hand in hand. (p. 31)

This study illustrates this idea that unity can often come with a price. Religion and relationships both demand time and resources, which are limited, and thus unity in certain relationships might result in disunity or division in other relationships.

Thus far, unity and division have been described as helpful and harmful for the parent-child unit-as is the focus of this article. However, what is best for the parent-child relationship might not always be what is best for the individual. Division is not always inherently negative. The model presented by Dollahite et al. (2018) described unifying influences as "stabilizing" and dividing influences as "dynamic" and discussed the need to find balance between the two. When religion does have a divisive influence on a relationship, it does not necessarily mean that religion is negative for the individuals. For example, this analysis identified that religion had a dividing influence on parents and children when there was dissonance between the religious beliefs and practices and popular culture or the child's peer group. Division between parents and children in this instance might be accompanied by greater unity in the child's peer relationships. The resulting tension between the child's parents and their friends might help the child develop their own ideas, opinions, and identity. This is an important concept and warrants future research that investigates the unifying and dividing influence of religion on familial relationships along with relationships outside the family.

This idea that unity in one relationship might be accompanied by division in another relationship is also illustrated by comparing the results of a preceding study, published in Psychology of Religion and Spirituality, which used the same dataset and methods to look at uniting and dividing influences of religion in marriage (Kelley et al., 2020). This preceding study found that some genderbased beliefs and practices appeared to have a dividing influence between husbands and wives. Although beliefs regarding gender were not identified as having either a unifying or dividing influence on parent-child relationships, the current study did identify gender-based practices as having a unifying influence in parentchild relationships when they provided meaningful one-on-one time for mothers and daughters, and fathers and sons to spend together. Future research could build from these studies and employ quantitative methods to assess the correlation between the unifying influence of religion in certain relationships and its dividing influence in other relationships.
The finding that gendered religious practices can be both unifying and dividing also illustrates and echoes the finding from preceding articles, indicating that religion is often a tool, rather than a force in and of itself. Although some beliefs and practices might be prone to having a more unifying or divisive influence than others, these findings suggest that the more important factor is how the beliefs and practices are applied, rather than what they are. For example, the data shows that time spent together at worship services, praying, or participating in other religious practices is typically a positive, unifying experience for parents and children. However, the same practices could be divisive if children perceive them as taking too much time away from other activities or as interfering with how they wanted their peers to perceive them.

Why some practices, beliefs, and community interactions are unifying for some parent-child relationships and divisive for others might also be connected to how much the children are willing to sacrifice for their parents and their religion. An important tenet of all major religions is some form of required sacrifice from adherents. However, Smith and Denton (2009) found that despite a surprising amount of youth self-reporting as religious, the youth they interviewed reported that their religion was more about "feeling good, happy, secure, and at peace" (p. 163). Despite these trends related to sacrifice, a qualitative study found that some highly religious youth are willing to make substantial sacrifices for their religion (Dollahite, Layton, Bahr, Walker, \& Thatcher, 2009). However, more recent research suggests that this trend toward what Smith and Denton (2009) termed "moralistic therapeutic deism" (p. 163) appears to be continuing to increase (Willoughby et al., in press), and thus more recent research is needed to better understand religious sacrifices of youth today. Future research should explore whether religion has more of unifying or dividing influence on parent-child relationships might be explained, or mediated in part, by children's willingness to sacrifice.

Another potential mediating factor might be parent-child communication. Research exploring religious communication between parents and children found positive outcomes for youth-centered communication as opposed to parent-centered communication (Dollahite \& Thatcher, 2008). Perhaps the type of communication used in discussing religion could also help explain why religion is unifying for some parents and children and divisive for others. Relatedly, what parents talk about with their children might also be influential. For example, a recent study found that parents also struggle reconciling the way their religion clashes with their materialistic values (LeBaron, Kelley, Hill, \& Galbraith, 2019), a theme identified as creating conflict between parents and children our sample. As shared struggles, when successfully navigated, might have the potential to foster unity in a relationship (Dollahite, Marks, \& Young, 2019), future research should investigate whether parental self-disclosure regarding their own religious struggles to their children has a unifying influence on the relationship. An additional mediator might be how rigid or flexible parents are in their approach to religious beliefs, practices, and communities, as previous research has suggested that excessive rigidity can be detrimental for parent-child relationships, including leading to disunity and dysfunction (Dollahite, Marks, Babcock, Barrow, \& Rose, 2019).

A final, noteworthy finding that also mirrors the preceding study on marital relationships, is that the unifying and dividing influ- 
ences of beliefs and practices on parent-child relationships were more prevalent than the unifying and dividing influence of community. Although community played an important role in unifying parent-child relationships, its divisive role was nearly nonexistent in this study, with only seven coded accounts. However, again, it is important to note that this is in part due to the coding criteria used, where attending religious worships services was coded as a practice, rather than as community. Despite this, findings suggest that what takes place within the home might be more influential for most parent-child relationships than the interactions that take place outside of the home.

\section{Limitations and Directions for Future Research}

Although our sample has many strengths, including its racial, religious, and geographic diversity and its large size of 198 families ( $N=476$ individuals), it was not without limitations. First, our sample included only religious, same-faith, heterosexual marriage-based families from Abrahamic faiths. Future research should investigate the unifying and dividing influence of religion on interfaith families, families who are both moderately and marginally religious, diverse family structures, and include faiths outside of the Abrahamic tradition. Although there are many important and distinct differences within these Abrahamic faiths, such differences are often much more pronounced when Abrahamic and Eastern religious traditions are compared. Although ethics and the value of family is typically shared across all world religions, these religious traditions still "diverge sharply on doctrine, ritual, mythology, experience, and law" (Prothero, 2011, p. 3 ). Thus, though it is possible that there are some similarities between the unifying and dividing themes identified here and unifying and dividing influences of religion outside of Islam, Judaism, and Christianity, this is something for future research to investigate as this sample cannot be generalized to other religious groups.

An additional limitation of our study is that we interviewed parents and children together. Although there are certain benefits to this method (Dollahite \& Thatcher, 2008; Lofland \& Lofland, 1995), there are also several limitations. Some children might be susceptible to social desirability bias and give responses that will please their parents rather than reporting their true feelings and opinions (Havermans, Vanassche, \& Matthijs, 2015). Although results showed that some children did feel comfortable reporting some divisive influences of religion with their parents present, it is possible that there would have been more dividing accounts if parents and children had been interviewed separately. On the other hand, it is possible that the joint parent-youth interview approach elicited more conflict because parents and youth heard what each other said and could (and did) express disagreement with the other person's comment. An additional limitation is that we interviewed nearly five times as many parents as children. This resulted in parents' voices being more prominent than children's voices. However, we do note that the parents we interviewed also provided some accounts regarding their relationships with their own parents, and thus in some instances provided perspectives as both parents and children. We also note that children were aged from 10 to 25 years. Although this is a substantial age range, there is more that could be learned from younger children as well (Ridgely, 2011). Future research should make efforts to better highlight children's voices, including investigating younger children's reports of the uniting and dividing influences of religion.

The current study is exploratory in nature. Future research should build from this study and conduct a more in-depth analysis of the unifying and dividing influences of beliefs, practices, and community described in Table 1 , including their prevalence in families and differences by religion, family size, region, age, political ideology, geography, and so forth. Further, this study only investigated religion's unifying and dividing influence on parentchild relationships. To better understand the implications of the unifying and dividing nature of religion, other familial and extrafamilial relationships also should be investigated.

\section{Conclusion}

For the parents and children in this study, religion reportedly had both a unifying and a dividing influence on their relationships with each other. Although religion was most commonly identified as a unifying influence, despite the highly religious nature of our sample, a substantial number of dividing accounts were also identified. Religion appeared to have a dividing influence particularly when the religious values and what the parents' wanted their children to do conflicted with what the children wanted to do or how they wanted to be perceived by peers outside of the religious community. Although this study used rigorous qualitative methods and investigated three dimensions of religion, more research is needed to build upon this study and identify additional ways religion can be a relationally unifying and divisive force in both familial and extrafamilial relationships.

\section{References}

Agius, E., \& Chircop, L. (1998). Caring for future generations: Jewish, Christian, and Islamic perspectives. Westport, CT: Praeger.

Bartkowski, J. P., Xu, X., \& Levin, M. L. (2008). Religion and child development: Evidence from the early childhood longitudinal study. Social Science Research, 37, 18-36. http://dx.doi.org/10.1016/j .ssresearch.2007.02.001

Bernard, H. R., Wutich, A., \& Ryan, G. W. (2016). Analyzing qualitative data: Systematic approaches. Thousand Oaks, CA: SAGE.

Bornstein, M. H., Putnick, D. L., Lansford, J. E., Al-Hassan, S. M., Bacchini, D., Bombi, A. S., . . . Alampay, L. P. (2017). 'Mixed blessings': Parental religiousness, parenting, and child adjustment in global perspective. Journal of Child Psychology and Psychiatry, and Allied Disciplines, 58, 880-892. http://dx.doi.org/10.1111/jcpp.12705

Boyatzis, C. (2011). Agency, voice, and maturity in children's religious and spiritual development. In S. B. Ridgely (Ed.), The study of children in religions: A methods handbook (pp. 19-32). New York, NY: New York University Press. http://dx.doi.org/10.18574/nyu/9780814776469 .003 .0002

Burr, W. R., Marks, L. D., \& Day, R. (2012). Sacred matters: Religion and spirituality in families. New York, NY: Routledge. http://dx.doi.org/10 $.4324 / 9780203641323$

Chelladurai, J. M., Dollahite, D. C., \& Marks, L. D. (2018). “The family that prays together ...": Relational processes associated with regular family prayer. Journal of Family Psychology, 32, 849-859. http://dx .doi.org/10.1037/fam0000432

Daly, K. (2008). Qualitative methods for family studies and human development. Thousand Oaks, CA: SAGE.

Denzin, N., \& Lincoln, Y. (1994). Handbook of qualitative research. Thousand Oaks, CA: SAGE.

Dollahite, D. C., Layton, E., Bahr, H. M., Walker, A. B., \& Thatcher, J. Y. (2009). Giving up something good for something better: Sacred sacri- 
fices made by religious youth. Journal of Adolescent Research, 24, 691-725. http://dx.doi.org/10.1177/0743558409343463

Dollahite, D. C., Marks, L. D., Babcock, K. P., Barrow, B. H., \& Rose, A. H. (2019). Beyond religious rigidities: Religious firmness and religious flexibility as complementary loyalties in faith transmission. Religions. Advance online publication. http://dx.doi.org/10.3390/ rel10020111

Dollahite, D. C., Marks, L. D., \& Dalton, H. (2018). Why religion helps and harms families: A conceptual model of a system of dualities at the nexus of faith and family life. Journal of Family Theory \& Review, 10, 219-241. http://dx.doi.org/10.1111/jftr.12242

Dollahite, D. C., Marks, L. D., \& Goodman, M. A. (2004). Families and religious beliefs, practices, and communities. In M. Coleman \& L. Ganong (Eds.), Handbook of contemporary families (pp. 411-431). Thousand Oaks, CA: SAGE. http://dx.doi.org/10.4135/9781412976022 .n24

Dollahite, D. C., Marks, L. D., \& Young, K. P. (2019). Relational struggles and experiential immediacy in religious American families. Psychology of Religion and Spirituality, 11, 9-21. http://dx.doi.org/10.1037/ rel0000135

Dollahite, D. C., \& Thatcher, J. Y. (2008). Talking about religion: How highly religious youth and parents discuss their faith. Journal of Adolescent Research, 23, 611-641. http://dx.doi.org/10.1177/074355840 8322141

Exline, J. J., Pargament, K. I., Grubbs, J. B., \& Yali, A. M. (2014). The religious and spiritual struggles scale. Psychology of Religion and Spirituality, 6, 208-222. http://dx.doi.org/10.1037/a0036465

Exline, J. J., \& Rose, E. (2005). Religious and spiritual struggles. In R. F. Paloutzian \& C. L. Park (Eds.), Handbook of the psychology of religion (pp. 315-330). New York, NY: Guilford Press.

Handel, G. (1996). Family worlds and qualitative family research: Emergence and prospects of whole-family methodology. Marriage \& Family Review, 24, 335-348. http://dx.doi.org/10.1300/J002v24n03_06

Havermans, N., Vanassche, S., \& Matthijs, K. (2015). Methodological challenges of including children in family research: Measurement equivalence, selection bias and social desirability. Child Indicators Research, 8, 975-997. http://dx.doi.org/10.1007/s12187-014-9275-1

Henderson, W. M., Uecker, J., \& Stroope, S. (2016). The role of religion in parenting satisfaction and parenting stress among young parents. The Sociological Quarterly, 57, 675-710. http://dx.doi.org/10.1111/tsq .12147

Jorgensen, B. L., Mancini, J. A., Yorgason, J., \& Day, R. (2016). Religious beliefs, practices, and family strengths. Psychology of Religion and Spirituality, 8, 164-174. http://dx.doi.org/10.1037/rel0000052

Kelley, H. H., LeBaron, A. B., Sussman, L. J., Fagan, J., Dollahite, D. C., \& Marks, L. D. (2018). Shalom bayit-Peace of the home: Ritual and tradition in American Jewish families. Marriage \& Family Review, 54, 706-718. http://dx.doi.org/10.1080/01494929.2018.1478922

Kelley, H. H., Marks, L. D., \& Dollahite, D. C. (2020). Uniting and dividing influences of religion in marriage among highly religious couples. Psychology of Religion and Spirituality, 12, 167-177. http://dx .doi.org/10.1037/rel0000262

King, P. E., \& Boyatzis, C. J. (2015). Religious and spiritual development. In R. M. Lerner (Ed.), Handbook of child psychology and developmental science (7th ed., pp. 975-1023). New York, NY: Wiley. http://dx.doi .org/10.1002/9781118963418.childpsy323

Krause, N. (2008). Aging in the church: How social relationships influence health. West Conshohocken, PA: Templeton.

Lambert, N. M., Fincham, F. D., LaVallee, D. C., \& Brantley, C. W. (2012). Praying together and staying together: Couple prayer and trust. Psychology of Religion and Spirituality, 4, 1-9. http://dx.doi.org/10 $.1037 / \mathrm{a} 0023060$
Landis, J. R., \& Koch, G. G. (1977). The measurement of observer agreement for categorical data. Biometrics, 33, 159-174. http://dx.doi .org/10.2307/2529310

LeBaron, A. B., Kelley, H. H., Hill, E. J., \& Galbraith, Q. (2019). Finances, religion, and the FAAR model: How religion exacerbates and alleviates financial stress. Psychology of Religion and Spirituality. Advance online publication. http://dx.doi.org/10.1037/re10000294

Levitt, H. M., Bamberg, M., Creswell, J. W., Frost, D. M., Josselson, R., \& Suárez-Orozco, C. (2018). Journal article reporting standards for qualitative primary, qualitative meta-analytic, and mixed methods research in psychology: The APA Publications and Communications Board Task Force report. American Psychologist, 73, 26-46. http://dx .doi.org/10.1037/amp0000151

Lofland, J., \& Lofland, L. H. (1995). Analyzing social settings. Belmont, CA: Wadsworth.

MacQueen, K., McLellan, E., Kay, K., \& Milstein, B. (1998). Codebook development for team-based qualitative analysis. Cultural Anthropology Methods, 10, 31-36. http://dx.doi.org/10.1177/1525822x980100020301

Mahoney, A. (2005). Religion and conflict in marital and parent-child relationships. Journal of Social Issues, 61, 689-706. http://dx.doi.org/ 10.1111/j.1540-4560.2005.00427.x

Mahoney, A. (2010). Religion in families 1999 to 2009: A relational spirituality framework. Journal of Marriage and the Family, 72, 805827. http://dx.doi.org/10.1111/j.1741-3737.2010.00732.x

Marks, L. D. (2005). Religion and bio-psycho-social health: A review and conceptual model. Journal of Religion and Health, 44, 173-186. http:// dx.doi.org/10.1007/s10943-005-2775-Z

Marks, L. D. (2015). A pragmatic, step-by-step guide for qualitative methods. Current Psychology, 34, 494-505. http://dx.doi.org/10.1007/ s12144-015-9342-x

Marks, L. D., \& Dollahite, D. C. (2017). Religion and families: An introduction. New York, NY: Routledge. http://dx.doi.org/10.4324/ 9781315814599

Murray-Swank, A., Mahoney, A., \& Pargament, K. I. (2006). Sanctification of parenting: Links to corporal punishment and parental warmth among biblically conservative and liberal mothers. The International Journal for the Psychology of Religion, 16, 271-287. http://dx.doi.org/ 10.1207/s15327582ijpr1604_3

Nelson, J. J., \& Uecker, J. E. (2018). Are religious parents more satisfied parents? Individual- and couple level religious correlates of parenting satisfaction. Journal of Family Issues, 39, 1770-1796. http://dx.doi.org/ 10.1177/0192513X17728983

NVivo 10. (2014). QSR International [Computer software]. Retrieved from https://www.qsrinternational.com/nvivo-qualitative-data-analysissoftware/home

NVivo 11. (2015). QSR International [Computer software]. Retrieved from https://www.qsrinternational.com/nvivo-qualitative-data-analysissoftware/home

Petts, R. J., \& Knoester, C. (2007). Parents' religious heterogamy and children's well-being. Journal for the Scientific Study of Religion, 46, 373-389. http://dx.doi.org/10.1111/j.1468-5906.2007.00364.x

Petts, R. J., \& Kysar-Moon, A. E. (2012). Child discipline and conservative Protestantism: Why the relationship between corporal punishment and child behavior problems may vary by religious context. Review of Religious Research, 54, 445-468. http://dx.doi.org/10.1007/s13644012-0080-3

Prothero, S. (2011). God is not one: The eight rival religions that run the world, and why their differences matter. New York, NY: Harper-Collins. http://dx.doi.org/10.1111/j.1468-5906.2010.01561_3.x

Regnerus, M. D., \& Uecker, J. E. (2006). Finding faith, losing faith: The prevalence and context of religious transformations during adolescence. Review of Religious Research, 47, 217-237. Retrieved from https:// www.jstor.org/stable/3512355 
Ridgely, S. B. (2011). Maybe the picture will tell you: Methods for hearing children's perspectives on religion. The study of children in religions: A methods handbook (pp. 80-94). New York, NY: New York University Press. http://dx.doi.org/10.18574/nyu/9780814776469.003.0006

Sacks, J. (2015). Not in God's name: Confronting religious violence. New York, NY: Schocken.

Silk, M., \& Walsh, A. (2011). One nation, divisible: How regional religious differences shape American politics. Lanham, MD: Rowman \& Littlefield.

Smith, C., \& Denton, M. L. (2009). Soul searching: The religious and spiritual lives of American teenagers. New York, NY: Oxford University Press.

Stokes, C. E., \& Regnerus, M. D. (2009). When faith divides family: Religious discord and adolescent reports of parent-child relations. Social Science Research, 38, 155-167. http://dx.doi.org/10.1016/j .ssresearch.2008.05.002

Uecker, J. E., Regnerus, M. D., \& Vaaler, M. L. (2007). Losing my religion: The social sources of religious decline in early adulthood. Social Forces, 85, 1667-1692. http://dx.doi.org/10.1353/sof.2007.0083

Volling, B. L., Mahoney, A., \& Rauer, A. J. (2009). Sanctification of parenting, moral socialization, and young children's conscience devel- opment. Psychology of Religion and Spirituality, 1, 53-68. http://dx.doi .org/10.1037/a0014958

Weyand, C., O'Laughlin, L., \& Bennett, P. (2013). Dimensions of religiousness that influence parenting. Psychology of Religion and Spirituality, 5, 182-191. http://dx.doi.org/10.1037/a0030627

White, T., Chelladurai, J. M., Monroe, P. A., Garand, J. C., Dollahite, D. C., \& Marks, L. D. (2018). Kept together by faith: Confession and forgiveness among American Catholic and Orthodox Christian families. Marriage \& Family Review, 54, 677-692. http://dx.doi.org/10.1080/ 01494929.2018 .1469573

Wilcox, W. B. (2004). Soft patriarchs, new men: How Christianity shapes fathers and husbands. Chicago, IL: University of Chicago Press.

Willoughby, B. J., Marks, L. D., \& Dollahite, D. C. (in press). Diverse trajectories at the intersection of religion and sex during emerging adulthood. In M. Van Dulmen \& E. Morgan (Eds.), Sexuality in emerging adulthood. New York, NY: Oxford University Press.

Received October 15, 2019

Revision received March 7, 2020

Accepted March 13, 2020 